\title{
Apocrine Hidrocystoma of the Lower Lip: A Case Report and Literature Review
}

\author{
Kentaro Kikuchi $\cdot$ Shuichi Fukunaga \\ Harumi Inoue $\cdot$ Yuji Miyazaki · Fumio Ide • \\ Kaoru Kusama
}

Received: 6 March 2013/Accepted: 24 May 2013/Published online: 6 June 2013

(C) Springer Science+Business Media New York 2013

\begin{abstract}
The hidrocystomas (HCs) are cystic forms of sweat gland resulting from proliferation of the apocrine secretory coil or eccrine duct. Apocrine -HCs are cystic lesions that arise from the apocrine secretory coil, while eccrine -HCs represent retention cysts of the eccrine duct. The commonest site for such lesions is around the eye, and they may also occur on the ears, scalp, chest, shoulders, or feet. However, HCs of the perioral region are uncommon. The differential diagnosis with minor salivary gland cyst or cystic neoplasms often poses a problem in this site. Here we report a rare case of apocrine - $\mathrm{HC}$ of the right lower lip for which excisional biopsy of the lesion was performed. Histopathologically, the lesion was a unilocular cyst lined by a double-layered epithelium of the apocrine secretory type. Immunohistochemically, the secretory epithelium was positive for mammaglobin, gross cystic disease fluid protein 15 (GCDFP-15), cytokeratin 7 (CK 7) and CK18,
\end{abstract}

\author{
K. Kikuchi $(\bowtie) \cdot$ H. Inoue · Y. Miyazaki · F. Ide · K. Kusama \\ Division of Pathology, Department of Diagnostic and \\ Therapeutic Sciences, Meikai University School of Dentistry, \\ 1-1 Keyakidai, Sakado, Saitama 350-0283, Japan

and the myoepithelium was positive for alpha-smooth muscle actin ( $\alpha$-SMA) and weakly positive for S100 protein. Here we present this very rare case of apocrine -HC of the lower lip, and discussed regarding differential diagnosis with minor salivary gland cystic lesion in the lip.

Keywords Apocrine hidrocystoma - Lip · Mammaglobin . GCDFP-15 $\cdot$ CK $7 \cdot$ CK18 1 S100 $\cdot \alpha$-SMA

\section{Introduction}

Apocrine hidrocystoma (-HC), also called apocrine cystadenoma, is a benign cystic tumor-like lesion usually presenting as a solitary translucent nodule of cystic consistency [1]. Apocrine - $\mathrm{HC}$ arises not from eccrine glands (duct and coil) but from the secretory coil of apocrine sweat glands [1,2]. Eccrine-HC appears as a retention cyst of the eccrine duct [2]. Histologically, apocrine - HC can be differentiated from eccrine -HC by the presence of secretory cells showing decapitation secretion. Immunohistochemically, apocrine -HC is positive for human milk fat globules, GCDFP-15, CK 7 and $\alpha$-SMA, whereas eccrine -HC is negative for all of them [3, 4]. Apocrine -HC expresses a secretory-type keratin pattern, whereas eccrine -HC expresses an excretory-type keratin pattern [3]. These lesions are usually located on the face and neck, mainly the periorbital area. However, apocrine -HC developing on the lower lip is very rare, and clinico-pathologically problem point is differential diagnosis between dermal sweet gland lesion and minor salivary gland lesion in this site. Previous reports of apocrine- and eccrine -HCs affecting the lip are listed in Table $1[3,5,6]$. In fact, the English literature contains very little information on HCs of the lip $[3,5,6]$. 
Table 1 Summary of clinicopathological findings in hidrocystoma (HC) of the lip

\begin{tabular}{|c|c|c|c|c|c|c|c|c|c|c|c|c|c|c|}
\hline \multirow{2}{*}{$\begin{array}{l}\text { Author } \\
\text { [ref.] }\end{array}$} & \multirow[t]{2}{*}{ Age } & \multirow[t]{2}{*}{ Sex } & \multirow{2}{*}{$\begin{array}{l}\text { Number } \\
\text { (localization) } \\
\text { (size) }\end{array}$} & \multirow{2}{*}{$\begin{array}{l}\text { Clinical } \\
\text { diagnosis }\end{array}$} & \multirow{2}{*}{$\begin{array}{l}\text { Pathological } \\
\text { diagnosis }\end{array}$} & \multicolumn{9}{|c|}{ Immunohistochemistry } \\
\hline & & & & & & CK7 & CK8 & CK18 & CK19 & EMA & S100 & $\alpha$-SMA & $\begin{array}{l}\text { Mamma- } \\
\text { globin/ } \\
\text { (HMFG) }\end{array}$ & $\begin{array}{l}\text { GCDFP- } \\
15\end{array}$ \\
\hline $\begin{array}{l}\text { De Viragh } \\
\text { PA et al. } \\
\text { [3] }\end{array}$ & 73 & $\mathrm{~F}$ & $\begin{array}{l}\text { Multiple } \\
\text { (lip) } \\
\text { (?) }\end{array}$ & $\mathrm{HC}, \mathrm{BCC}$ & Eccrine $\mathrm{HC}$ & - & - & - & NA & NA & NA & - & - & NA \\
\hline $\begin{array}{l}\text { Willard K } \\
\text { et al. [5] }\end{array}$ & 65 & $\mathrm{~F}$ & $\begin{array}{l}\text { Solitary } \\
\text { (right upper lip) } \\
(2 \mathrm{~mm})\end{array}$ & $\mathrm{HC}, \mathrm{BCC}$ & Eccrine $\mathrm{HC}$ ? & NA & NA & NA & NA & NA & NA & NA & NA & NA \\
\hline $\begin{array}{l}\text { Andersen } \\
\text { WA et al. } \\
\text { [6] }\end{array}$ & 39 & M & $\begin{array}{l}\text { Solitary } \\
\text { (right lip) } \\
(2 \mathrm{~mm})\end{array}$ & Cyst & $\begin{array}{l}\text { Hybrid epidermoid } \\
\text { and apocrine cyst }\end{array}$ & NA & NA & NA & NA & NA & NA & NA & NA & - \\
\hline Our case & 64 & M & $\begin{array}{l}\text { Solitary } \\
\text { (right lower lip) } \\
(4 \times 4 \mathrm{~mm})\end{array}$ & Tumor & Apocrine $\mathrm{HC}$ & $\begin{array}{l}+ \\
\text { I-Cs }\end{array}$ & $\begin{array}{l}+ \\
\text { I-Cs }\end{array}$ & $\begin{array}{l}+ \\
\text { I-Cs }\end{array}$ & $\begin{array}{l}+ \\
\text { I-Cs }\end{array}$ & $\begin{array}{l}+ \\
\text { I-Cs } \\
\text { B-Cs }\end{array}$ & $\begin{array}{l}+ \\
\text { I-Cs } \\
\text { B-Cs }\end{array}$ & $\begin{array}{l}+ \\
\mathrm{My}-\mathrm{Cs}\end{array}$ & $\begin{array}{l}+ \\
\text { I-Cs }\end{array}$ & $\begin{array}{l}+ \\
\text { I-Cs }\end{array}$ \\
\hline
\end{tabular}

$M$ mail, $F$ female, $H C$ hidrocystoma, $B B C$ basal cell carcinoma, $I$ - $C s$ inner cells, $B$ - $C s$ basal cells, $M y$ - $C s$ myoepithelial cells, $C K$ cytokeratin, $E M A$ epithelial membrane antigen, $\alpha S M A$ alpha-smooth muscle actin, $H M F G$ human milk fat globule, $G C D F P-15$ gross cystic disease fluid protein $15,+$ positive, - negative, $N A$ not available, ? unknown

Here we report an extremely rare case of apocrine -HC on the lower lip, including its histological and immunohistochemical features, and discuss the differences between HCs and minor salivary gland cystic lesions.

\section{Materials and Methods}

\section{Case Report}

A 64-year-old Japanese man was referred to Hanyu General Hospital because of a pain-less mass $(4 \times 4 \mathrm{~mm})$ in the right lower lip with normal coloration (Fig. 1). The clinical diagnosis was a suspected tumor, and the lesion was resected under local anesthesia. Macroscopically, the surgical specimen was a cystic lesion with a smooth surface (Fig. 2a). Microscopic examination showed that the lesion contained multilocular spaces (Fig. 2b). The cystic ducts were lined mainly by double -layered epithelium (Fig. 3), with no evidence of squamous or mucous metaplasia. Occasional ductal components showed diffusely apocrine-like secretory epithelium, and focal papillary epithelial hyperplasia without a vascular core (Fig. 3). Immunohistochemistry showed that the myoepithelial cells of the cystic wall were positive for $\alpha$-SMA (Fig 4a), and that the proliferative activity (MIB 1 index) of the cystic epithelium was low, at about $<1 \%$ (Fig. 4b). The apocrine-like secretory epithelium was positive for mammaglobin and GCDFP-15 (Fig. 4c, d). CK7, CK14 (data not shown), CK18 and CK19 were expressed in the luminal cell layer of the cystic lining epithelium (Fig. 4e-g). EMA and S100 protein were expressed in the basal and luminal cell layers (data not show). Myoepithelial cells were weakly positive for S100 protein (data not show). These histological findings indicated that the lesion was compatible with apocrine -HC of the lower lip.

The case study protocol was reviewed and approved by the Research Ethics Committee of Meikai University School of Dentistry (A0832).

Immunohistochemistry

Deparaffinized sections were immersed in absolute methanol containing $0.3 \% \mathrm{H}_{2} \mathrm{O}_{2}$ for $15 \mathrm{~min}$ at room temperature to block endogenous peroxidase activity. After washing, the sections were immersed in $0.01 \mathrm{M}$ citrate

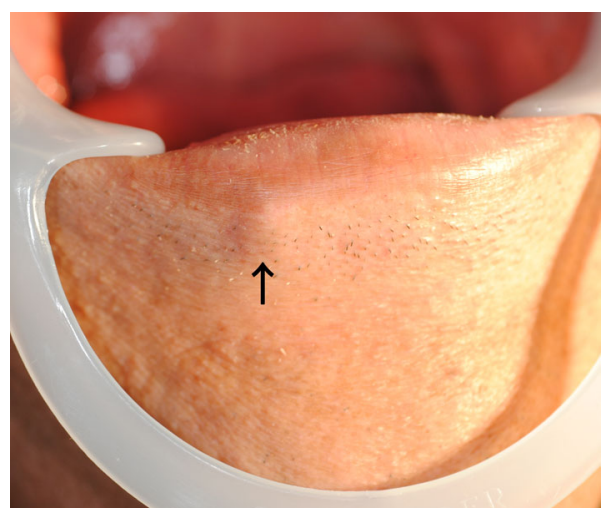

Fig. 1 A swelling lesion with normal color in the right lower lip-skin (arrow) 

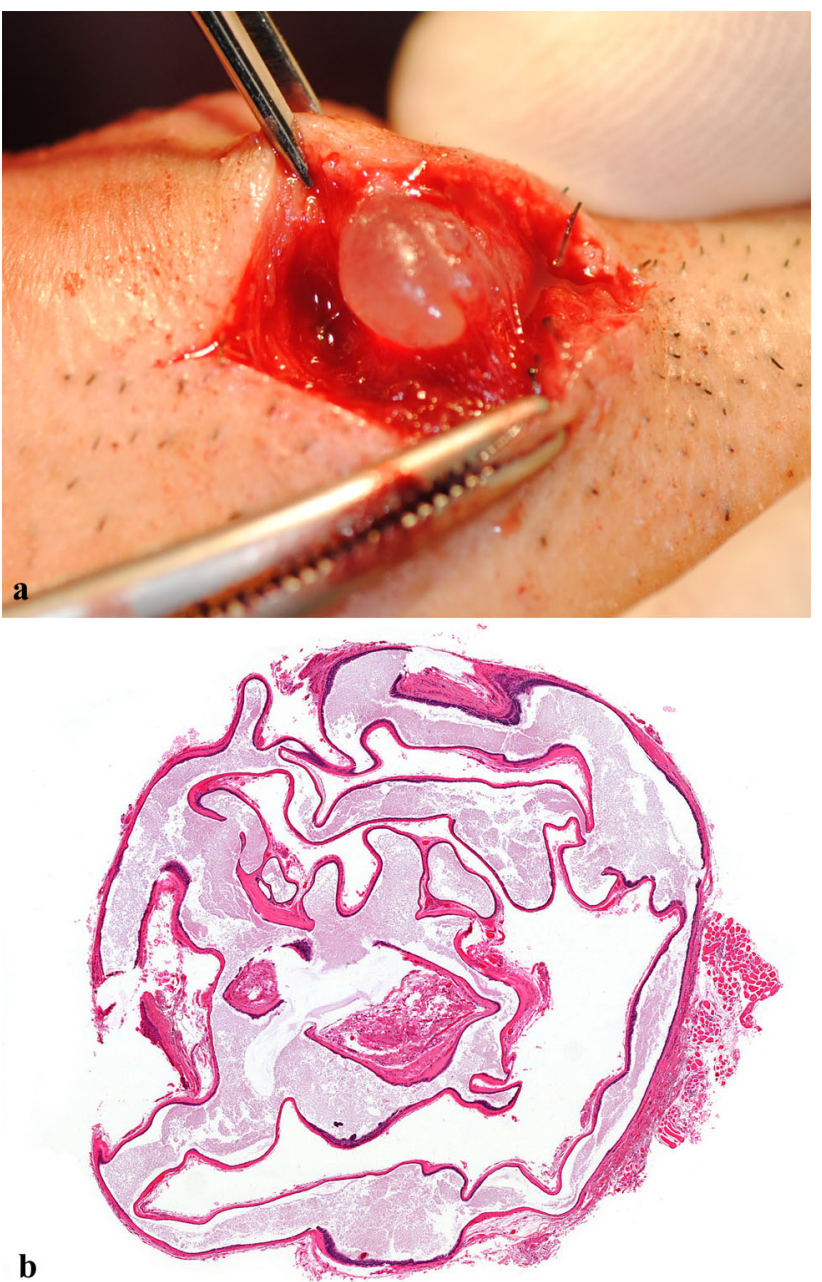

Fig. 2 Surgical and microscopic features of the lesion. a A cystic lesion with capsule preserved in subepidermis. $\mathbf{b}$ The survey view of the resected specimen shows an encapsulated multi-loculated solid cyst and irregular cystic space with eosinophilic fluids (HE, original magnification $\times 12.5$ )

buffer, $\mathrm{pH}$ 6.0, and heated in a microwave oven for $5 \mathrm{~min}$ at high voltage and then for $15 \mathrm{~min}$ at low voltage. They were then incubated with each of the appropriately diluted antibodies listed in Table 2. After washing, the sections were incubated with a pre-diluted anti-mouse or rabbit IgG antibody conjugated with peroxidase (Nichirei, Tokyo, Japan) for $30 \mathrm{~min}$ at room temperature. They were then immersed for $8 \mathrm{~min}$ in $0.05 \% 3,3^{\prime}$-diaminobenzidine tetrahydrochloride (DAB) in $0.05 \mathrm{M}$ Tris- $\mathrm{HCl}$ buffer $(\mathrm{pH}$ 8.5) containing $0.01 \% \mathrm{H}_{2} \mathrm{O}_{2}$, and counterstained with Mayer's hematoxylin for $90 \mathrm{~s}$.

\section{Discussion}

Hidrocystomas are rare, benign skin adnexal cystic lesions [5]. On the basis of their histologic characteristics and presumed histogenic derivation, $\mathrm{HCs}$ have been

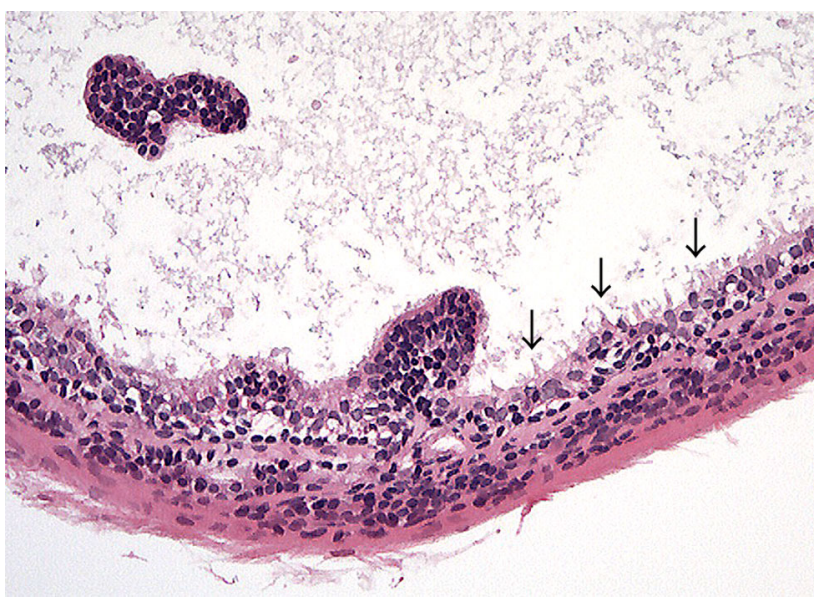

Fig. 3 Cyst wall covered by apocrine type epithelial cells with marked decapitation secretion "so-called" apocrine snout and fringe (arrowheads). Focally, papillary epithelial hyperplasia without vascular core was noted (HE, original magnification x100)

categorized into two types: apocrine- and eccrine -HCs. Apocrine -HC (apocrine cystadenoma), first described by Mehregan in 1964, is thought to be a benign skin cystic lesion derived from the secretory portion of the apocrine gland [1]. This lesion arises through proliferation of apocrine glands and is usually solitary, with a diameter of 3-15 mm [7, 8]. Apocrine lesions are also found mostly on the head and neck, and along the eyelid margin near the inner canthus [7]. Eccrine -HCs, first described by Robinson [9], present as small, tense, thin-walled cysts 1-6 $\mathrm{mm}$ in diameter, and can occur as single or multiple lesions $[7,8]$. They occur predominantly in adult females, being located mostly in the periorbital and malar regions $[7,8]$. Apocrine- and eccrine -HCs are prevalent in adults between 30 and 75 years of age, and the lesions are generally distributed in similar locations on the body $[7,8,10$, 11]. However, HCs in the lip-skin are very rare, and apocrine -HC of the lower lip is extremely rare (Table 1).

The most important pathological characteristics of apocrine- and eccrine -HCs are: (1) Clinically, solitary lesions are more likely to be apocrine - $\mathrm{HCs}$ than eccrine -HCs (multiple apocrine -HCs are found in Goltz-Gorlin syndrome and Schopf-Schulz-Passarge syndrome [12, 13]). (2) Morphologically, apocrine -HCs have a double lining of epithelium (inner layer, tall columnar or cuboidal cells) with decapitation secretion and an outer side consisting of myoepithelial cells, whereas eccrine - $\mathrm{HCs}$ are lined by flat epithelium without myoepithelial cells [3, 12]. (3) Immunohistochemically, apocrine -HCs are positive for human milk fat globules, GCDFP-15, CK7 and CK18 in the inner layer of epithelium, and also positive for $\alpha$-SMA in the outer myoepithelial cells, whereas eccrine -HCs are negative for all of these $[3,4,14,15]$. Therefore, the most 


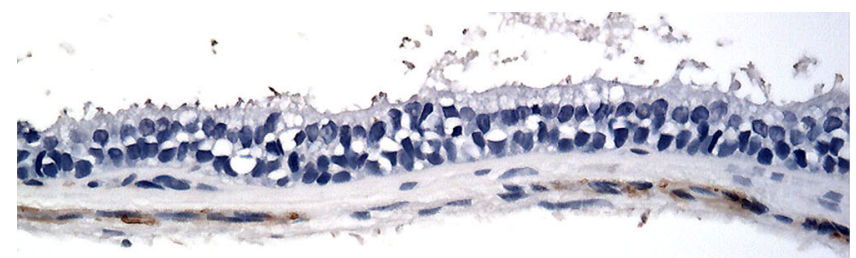

a
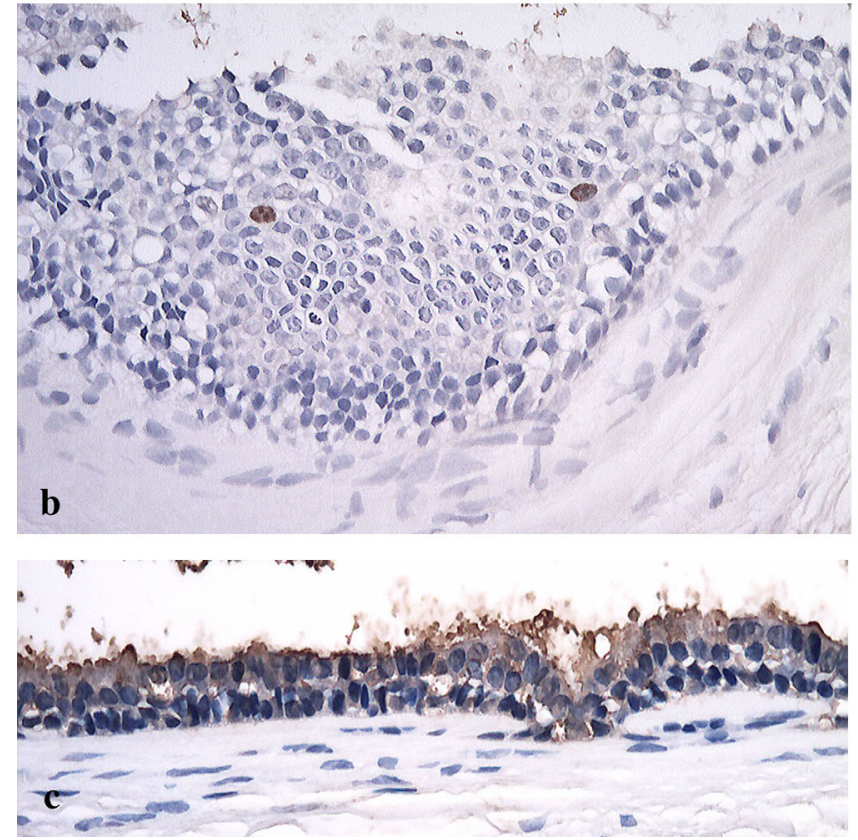

Fig. 4 Immunohistochemical features of the surgical specimen. a An outer layer of cystic wall was positive for $\alpha$-SMA (arrowheads), $b$ and proliferative activity (MIB 1 index) in the focal epithelial hyperplasia was low value (about $<1 \%$ ). c, $\mathbf{d}$ Apocrine-like secretory epithelium
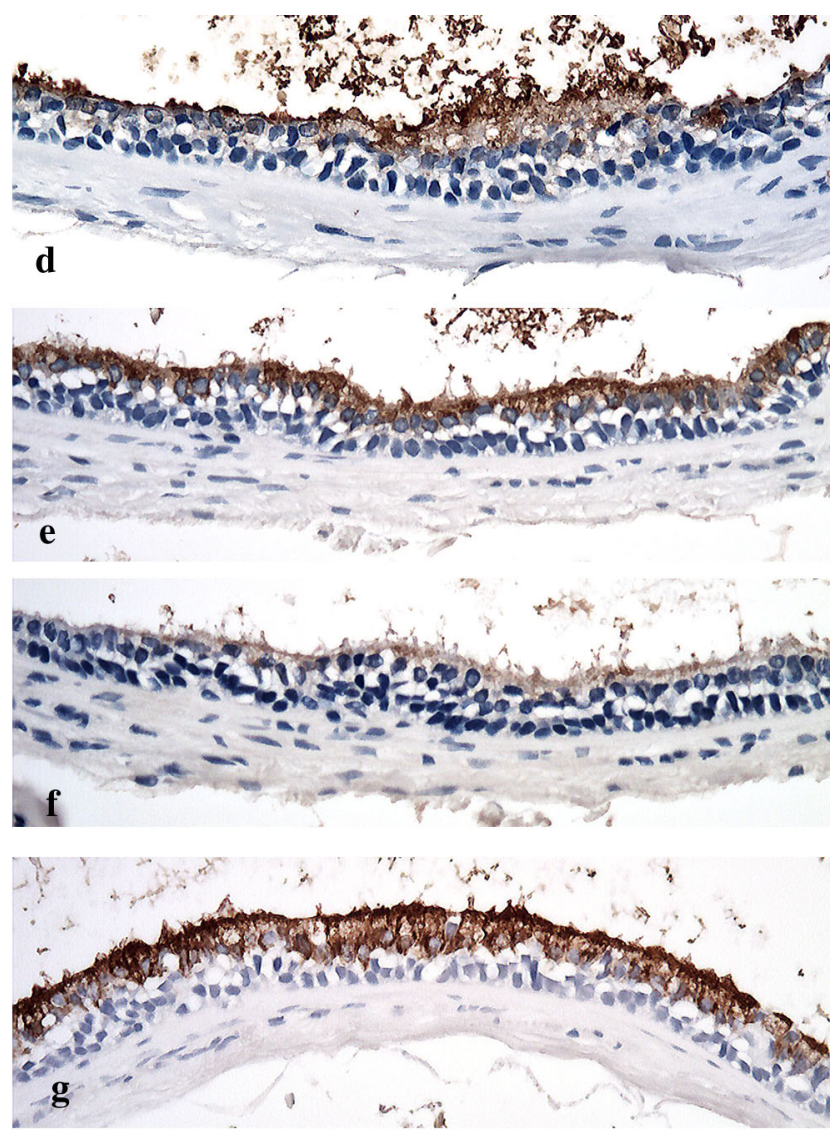

and secretory fluids were strongly positive for mammaglobin and GCDFP-15. e-g The luminal cell layer of the lining epithelium was positive for CK7, CK18 and CK19. (a-g, original magnification x100)

Table 2 Antibodies and dilutions used in this case

\begin{tabular}{lllll}
\hline Antigen & Clone & Dilution & Pretreatment & Source \\
\hline Cytokeratin 7 & OV-TL 12/30 & $1: 50$ (mouse monoclonal) & MW & Dako \\
Cytokeratin 14 & LL002 & $1: 50$ (mouse monoclonal) & MW & Chemicon international \\
Cytokeratin 18 & DC 10 & $1: 50$ (mouse monoclonal) & MW & Dako \\
Cytokeratin 19 & RCK 108 & $1: 50$ (mouse monoclonal) & MW & Dako \\
S100 protein & - & $1: 400$ (rabbit polyclonal) & - & Nichirei Biosciences \\
Ki-67 & MIB-1 & $1: 50$ (mouse monoclonal) & MW & Dako \\
Epithelial membran antigen (EMA) & E29 & $1: 1$ (mouse monoclonal) & - & Nichirei Biosciences \\
Alpha-smooth muscle actin ( $\alpha$-SMA) & 1A4 & $1: 1$ (mouse monoclonal) & - & Nichirei Biosciences \\
Mammaglobin & 31 A5 & $1: 1$ (rabbit polyclonal) & - & Biocare Medical \\
Gross cystic disease fluid protein 15 (GCDFP-15) & D6 & $1: 1$ (mouse monoclonal) & - & Biocare Medical \\
\hline
\end{tabular}

$M W$ microwave oven (for $5 \mathrm{~min}$ at high voltage and then for $10 \mathrm{~min}$ at low voltage); -, non

compatible pathological diagnosis in the present case was apocrine -HC.

Pathological diagnosis of $\mathrm{HCs}$ in the lip is need differentiating from minor salivary gland cyst or cystic tumors. The differential diagnosis includes cystic pleomorphic adenoma (CPA), Warthin tumor (WT), cystadenoma (CA), cystadenocarcinoma (CAC), mucoepidermoid carcinoma (MEC), salivary duct carcinoma (SDC), mucous retention cyst, salivary duct cyst, and sclerosing polycystic adenosis (SPA). Apocrine-HC lacks the myxoid to chondroid component and myoepithelial proliferation of CPA, and CPA lacks the apocrine-like secretory epithelium that 
characterized apocrine -HC. Likewise, WT, CA, CAC, MEC, SDC, mucous retention cyst, and salivary duct cyst lacks this feature. The most important differentiating minor salivary gland lesion is SPA because it is histomorphologically very similar to apocrine -HC. SPA are characterized by apocrine-like epithelium (GCDFP-15 positive) [15], nodular sclerosis, xanthomatous infiltrate, acinar-type cells, and foamy degeneration of cyst-lining epithel cells, however, apocrine -HC essentially lacks nodular sclerosis "scar-like hyalinized fibrous stroma" and these feature except for apocrine-like epithelium (GCDFP-15 positive). Furthermore, in our case is found to be a cystic lesion rather than a tumor by low positive rate of ki-67. Clinically, the sweet gland lesion or minor salivary gland lesions are distinguishable by swelling side of the skin or oral mucosa. In the present case is swelling skin in the lip, and surgically operated lesion is presented in the subepidermis.

De Viragh et al. [3] have reported that apocrine- or eccrine -HCs are often misdiagnosed because of masking of the usual histological criteria, probably secondary to the intraluminal pressure in the cysts, which flattens their walls and abolishes decapitation secretion. Furthermore, the immunohistochemical staining for CK8 or 19 may not be consistent, varying among manufacturers even for the same antibody $[14,16]$. Similary, their differentiation cannot be confirmed by staining for carcinoembryonic antigen (CEA) and epithelial membrane antigen (EMA) [4], and the use of S100 protein immunostaining for differentiating eccrine from apocrine cystic tumors is controversial [17-20]. HCs may be eccrine or apocrine, and a specific diagnosis is possible only after staining for human milk fat globules or GCDFP-15 [3].

Although many of the cystic lesions occurring in the lip are a minor salivary gland origin, $\mathrm{HC}$ which originates in skin sweet gland rarely may arise. The available literature suggests that distinction of eccrine- from apocrine - $\mathrm{HCs}$ can be achieved by immunohistochemical staining for human milk fat globules, GCDFP-15 or mammaglobin.

\section{References}

1. Hehregan AH. Apocline cystadenoma. A clinicopathologic study with special reference to the pigmented variety. Arch Dermatol. 1964;90:274-9.

2. McNiff J, McCalmont TH, Requena L, Sangüeza OP, Vassallo C, Rosso R, Borroni G, Glusac EJ, Pichardo RO. Benign tumours with apocrine and eccrine differentiation. In: LeBoit PE, Burg G, Weedon D, Sarasin A, editors. World Health Organization Classification of Tumours. Pathology and genetics of skin tumours. Lyon: IARC Press; 2006. p. 139-40.

3. De Viragh PA, Szeimies RM, Eckert F. Apocrine cystadenoma, apocrine hidrocystoma, and eccrine hidrocystoma: three distinct tumors defined by expression of keratins and human milk fat globulin 1. J Cutan Pathol. 1997;24(4):249-55.

4. Jakobiec FA, Zakka FR. A reappraisal of eyelid eccrine and apocrine hidrocystomas: microanatomic and immunohistochemical studies of 40 lesions. Am J Ophthalmol. 2011;151(2):358-74.

5. Willard K, Warschaw KE, Swanson DL. Use of reflectance confocal microscopy to differentiate hidrocystoma from basal cell carcinoma. Dermatol Surg. 2011;37(3):392-4.

6. Andersen WK, Rao BK, Bhawan J. The hybrid epidermoid and apocrine cyst. A combination of apocrine hidrocystoma and epidermal inclusion cyst. Am J Dermatopathol. 1996;18(4): 364-6.

7. Sarabi K, Khachemoune A. Hidrocystomas-a brief review. MedGenMed. 2006;8(3):57. Review.

8. Alfadley A, Al Aboud K, Tulba A, Mourad MM. Multiple eccrine hidrocystomas of the face. Int J Dermatol. 2001;40(2):125-9.

9. Robinson AR. Hidrocystoma. J Cutan Genito-Urin Dis. 1893;11:292-303.

10. Anderson PJ. Apocrine hydrocysadenoma of the ear. Otolaryngol Head Neck Surg. 2005;133(6):981-2.

11. Anzai S, Goto M, Fujiwara S, Da T. Apocrine hidrocystoma: a case report and analysis of 167 Japanese cases. Int J Dermatol. 2005;44(8):702-3.

12. Verma SB. Multiple apocrine hidrocystomas: a confusing clinical diagnosis. An Bras Dermatol. 2010;85(2):260-3. Review.

13. Castori M, Ruggieri S, Giannetti L, Annessi G, Zambruno G. Schöpf-Schulz-Passarge syndrome: further delineation of the phenotype and genetic considerations. Acta Derm Venereol. 2008;88(6):607-12.

14. Ohnishi T, Watanabe S. Immunohistochemical analysis of cytokeratin expression in apocrine cystadenoma or hidrocystoma. J Cutan Pathol. 1999;26(6):295-300.

15. Petersson F, Tan PH, Hwang JS. Sclerosing polycystic adenosis of the parotid gland: report of a bifocal, paucicystic variant with ductal carcinoma in situ and pronounced stromal distortion mimicking invasive carcinoma. Head Neck Pathol. 2011;5(2): 188-92.

16. Ohnishi T, Watanabe S. Immunohistochemical analysis of cytokeratin expression in multiple eccrine hidrocystoma. J Cutan Pathol. 1999;26(2):91-4.

17. Tokura $\mathrm{Y}$, Takigawa $\mathrm{M}$, Inoue $\mathrm{K}$, Matsumoto $\mathrm{K}$, Yamada $\mathrm{M}$. S-100 protein-positive cells in hidrocystomas. J Cutan Pathol. 1986;13(2):102-10.

18. Bourke JF, Colloby P, Graham-Brown RA. Multiple pigmented eccrine hidrocystomas. J Am Acad Dermatol. 1996;35(3):480-2.

19. Kato N, Ueno H. Eccrine hidrocystoma: two cases of Robinson and Smith types. J Dermatol. 1992;19(8):493-7.

20. Kanitakis J, Zambruno G, Viac J, Panzini H, Thivolet J. Expression of neural-tissue markers (S-100 protein and Leu-7 antigen) by sweat gland tumors of the skin. An immunohistochemical study. J Am Acad Dermatol. 1987;17:187-91. 